\title{
Dethiosulfovibrio salsuginis sp. nov., an anaerobic, slightly halophilic bacterium isolated from a saline spring
}

Correspondence

Sandra Baena

baena@javeriana.edu.co
C. Díaz-Cárdenas, ${ }^{1}$ G. López, ${ }^{1}$ B. K. C. Patel ${ }^{2}$ and S. Baena ${ }^{1}$

${ }^{1}$ Unidad de Saneamiento y Biotecnología Ambiental, Departamento de Biología, Pontificia Universidad Javeriana, POB 56710, Bogotá, Colombia

${ }^{2}$ Microbial Gene Research and Resources Facility, School of Biomolecular and Physical Sciences, Griffith University, Brisbane 4111, Australia

A mesophilic, strictly anaerobic, slightly halophilic bacterium, designated strain USBA $82^{\top}$, was isolated from a terrestrial saline spring in the Colombian Andes. The non-spore-forming curved rods $(5-7 \times 1.3 \mu \mathrm{m})$ with pointed or rounded ends, stained Gram-negative and were motile by means of laterally inserted flagella. The strain grew optimally at $30{ }^{\circ} \mathrm{C}$ (growth range $20-40{ }^{\circ} \mathrm{C}$ ), $\mathrm{pH} 7.3$ (growth range $\mathrm{pH} 5.5-8.5$ ) and $2 \%(\mathrm{w} / \mathrm{v}) \mathrm{NaCl}$ (growth range $0.1-7 \% \mathrm{NaCl}$ ). The strain fermented peptides, amino acids and a few organic acids, but growth was not observed on carbohydrates, alcohols or fatty acids. The strain reduced thiosulfate and sulfur to sulfide. Sulfate, sulfite, nitrate and nitrite were not used as electron acceptors. On peptone alone, acetate, succinate, propionate and traces of ethanol were formed, but in the presence of thiosulfate, acetate and succinate were formed. The $\mathrm{G}+\mathrm{C}$ content of the chromosomal DNA was $52 \mathrm{~mol} \%$ $\left(T_{\mathrm{m}}\right)$. 16S rRNA gene sequence analysis indicated that strain USBA $82^{\top}$ was affiliated to Dethiosulfovibrio peptidovorans within the phylum Synergistetes with a similarity value of approximately $93 \%$. Based on the differences between the new strain and the type species of the genus Dethiosulfovibrio, we suggest that strain USBA $82^{\top}$ represents a novel species of the genus for which the name Dethiosulfovibrio salsuginis sp. nov. is proposed. The type strain is USBA $82^{\top}\left(=\right.$ DSM $21565^{\top}=$ KCTC $\left.5659^{\top}\right)$.
The phylum Synergistetes (Jumas-Bilak et al., 2009) currently includes members of the genera Dethiosulfovibrio, Synergistes, Anaerobaculum, Aminobacterium, Thermanaerovibrio, Aminomonas, Thermovirga, Aminiphilus, Jonquetella and Cloacibacillus (Rees et al., 1997; Baena et al., 1998, 1999a, b; Dahle \& Birkeland, 2006; Díaz et al., 2007; Jumas-Bilak et al., 2007; Ganesan et al., 2008). A distinguishing feature that is common to all members of this phylum is the capacity to degrade amino acids (Vartoukian et al., 2007). Dethiosulfovibrio peptidovorans is the type species of the genus Dethiosulfovibrio. It was obtained from a corroding offshore oil well in Congo and is a non-saccharolytic peptide- and amino acid-degrading species which grows on several different amino acids in the presence of elemental sulfur or thiosulfate. During such growth, an increase in peptide utilization, cell yields and growth rates has been noted (Magot et al., 1997). In this report, we describe the characterization of a new Dethiosulfovibrio strain, isolated from the 'Salpa' saline spring.

As part of our ongoing research into the microbial diversity of the Salpa terrestrial saline spring, samples were collected

The GenBank/EMBL/DDBJ accession number for the 16S rRNA gene sequence of strain USBA $82^{\top}$ is EU719657. in sterile containers, the containers were capped, stored over ice, transported to the laboratory and maintained at $4{ }^{\circ} \mathrm{C}$ until used. The Salpa saline spring is located in the Andean region of Colombia at $2500 \mathrm{~m}$ above sea level. The spring has a constant temperature of $21{ }^{\circ} \mathrm{C}$ and a pH of 6.5 throughout the year. The predominant dissolved ion is sulfate $\left(20 \mathrm{~g} \mathrm{l}^{-1}\right)$ and the conductivity is approximately $50 \mathrm{mS} \mathrm{cm}{ }^{-1}$ (Alfaro, 2002).

Enrichments were initiated in a medium prepared by filtering saline spring water through polycarbonate membranes (Durapore) with a pore size of $0.22 \mu \mathrm{m}$. The medium was supplemented with peptone $(0.2 \%, \mathrm{w} / \mathrm{v})$, yeast extract $(0.02 \%, \mathrm{w} / \mathrm{v})$ and the trace element solution $\left(1 \mathrm{ml} \mathrm{l}^{-1}\right)$ as described by Imhoff-Stuckle \& Pfenning (1983). The medium was boiled and then cooled to room temperature under a stream of oxygen-free nitrogen. An $8 \mathrm{ml}$ aliquot was dispensed into Hungate tubes under oxygen-free nitrogen gas and sterilized by autoclaving at $121{ }^{\circ} \mathrm{C}$ for $20 \mathrm{~min}$ at a pressure of $1-1.5 \mathrm{~kg} \mathrm{~cm}^{-2}$. The enrichment medium was inoculated with $2 \mathrm{ml}$ water samples, incubated at $36{ }^{\circ} \mathrm{C}$ for up to two weeks and examined by phase-contrast light microscopy (Eclipse 50i; Nikon). 
To isolate pure cultures, serial dilutions of the enrichment cultures were made in an artificial basal medium (BM) fortified with $2 \%(\mathrm{w} / \mathrm{v})$ Noble agar using the roll-tube technique. $\mathrm{BM}$ contained $\left(\mathrm{l}^{-1}\right.$ deionized water): $1 \mathrm{~g} \mathrm{NH}_{4} \mathrm{Cl}$, $0.3 \mathrm{~g} \mathrm{~K}_{2} \mathrm{HPO}_{4}, 0.3 \mathrm{~g} \mathrm{KH}_{2} \mathrm{PO}_{4}, 3 \mathrm{~g} \mathrm{MgCl}_{2} .6 \mathrm{H}_{2} \mathrm{O}, 0.1 \mathrm{~g}$ $\mathrm{CaCl}_{2} .2 \mathrm{H}_{2} \mathrm{O}, 0.1 \mathrm{~g} \mathrm{KCl}, 23 \mathrm{~g} \mathrm{NaCl}, 1 \mathrm{ml}$ trace element solution (Imhoff-Stuckle \& Pfenning, 1983), 0.5 g cysteine$\mathrm{HCl}, 1.0$ g yeast extract and $0.5 \%(\mathrm{w} / \mathrm{v})$ peptone. The $\mathrm{pH}$ of the medium was adjusted to 7.1 with $1 \mathrm{M} \mathrm{NaOH}$ solution and then boiled, cooled and dispensed as described previously (Baena et al., 1998). Three morphologically similar cultures were isolated and $16 \mathrm{~S}$ rRNA gene sequences of all of the isolates showed an identical sequence (100\% similarity). One of the three isolates, designated strain USBA $82^{\mathrm{T}}$, was selected and studied further. The pure cultures were stored at $-80{ }^{\circ} \mathrm{C}$ in glycerol-BM $(20: 80)$.

Cell morphology was determined by phase-contrast microscopy. Samples for electron microscopy were prepared as described by Patel et al. (1985). Cells of strain USBA $82^{\mathrm{T}}$ were slightly curved rods with pointed or rounded ends $(5-7 \times 1.5 \mu \mathrm{m})$ and occurred singly or in pairs. Cells stained Gram-negative and were motile by laterally inserted flagella. Spores were not observed and exponential phase cultures were killed when heated to $90{ }^{\circ} \mathrm{C}$ for 5 min.

All growth studies were performed in duplicate in BM as described above. The novel strain was subcultured at least once under the same experimental conditions before use. To investigate the $\mathrm{pH}$ range for growth, studies were performed in $\mathrm{BM}$ adjusted to $\mathrm{pH}$ values between 4.0 and 9.0 with anoxic stock solutions of $\mathrm{NaHCO}_{3}(10 \%$, w/v), $\mathrm{Na}_{2} \mathrm{CO}_{3}(10 \% \mathrm{w} / \mathrm{v})$ or citrate buffer $(1 \mathrm{M})$. Strain USBA $82^{\mathrm{T}}$ grew between $\mathrm{pH} 5.5$ and 8.5 , with optimum growth at $\mathrm{pH}$ 7.3. The temperature range for growth was between 20 and $40{ }^{\circ} \mathrm{C}$, with optimum growth occurring at $30{ }^{\circ} \mathrm{C}$. To determine the $\mathrm{NaCl}$ tolerance of the strain, $\mathrm{NaCl}$ was added directly into the tubes to obtain the desired concentration and the $\mathrm{BM}$ was then added. Strain USBA $82^{\mathrm{T}}$ grew in concentrations of $0.1-7 \% \mathrm{NaCl}$, but not in $\mathrm{NaCl}$ concentrations below $0.1 \%$ or above $8 \%$. Cells grew optimally at $2 \% \mathrm{NaCl}(\mathrm{w} / \mathrm{v})$.

Thiosulfate $(10 \mathrm{mM})$, sulfate $(10 \mathrm{mM})$, sulfite $(5 \mathrm{mM})$, elemental sulfur $(3 \%, w / v)$, sodium nitrate $(20 \mathrm{mM})$ and sodium nitrite $(5 \mathrm{mM})$ were tested as electron acceptors in $\mathrm{BM}$ lacking yeast extract and supplemented with $0.2 \%$ $(\mathrm{w} / \mathrm{v})$ peptone rather than the usual $0.5 \%(\mathrm{w} / \mathrm{v}) . \mathrm{H}_{2} \mathrm{~S}$ production from the reduction of sulfate, sulfite, elemental sulfur and thiosulfate was determined using the method of Cord Ruwisch (1985). The reduction of nitrate, nitrite and ammonia was determined as described by Ogg \& Patel (2009). Strain USBA $82^{\mathrm{T}}$ was able to weakly reduce elemental sulfur and thiosulfate, but not sulfate, sulfite, nitrate or nitrite. Strain USBA $82^{\mathrm{T}}$ was unable to grow under aerobic conditions.

Substrate utilization tests were performed in the presence or absence of thiosulfate and sulfur in BM lacking peptone and amended with $0.025 \%(\mathrm{w} / \mathrm{v})$ yeast extract rather than $1.0 \%$. Substrates from autoclaved or filter-sterilized anaerobic stock solutions of monosaccharides, disaccharides, polysaccharides, sugar alcohols and peptides were added to a final concentration of $0.2 \%(\mathrm{w} / \mathrm{v})$ and organic acids and amino acids were added to a concentration of $10 \mathrm{mM}$. Growth was measured by inserting Hungate tubes into a Novaspec LKB spectrophotometer (PharmaciaBiotech Pty. Ltd) and monitoring the optical density at $580 \mathrm{~nm}$. Cultures were recorded as positive for growth if they exhibited an increase in optical density relative to controls (which lacked any added carbon sources). Strain USBA $82^{\mathrm{T}}$ fermented Casamino acids, peptone, tryptone, serine, histidine, threonine, arginine, glutamate, pyruvate and citrate. Growth did not occur on lysine, glycine, proline, valine, alanine, cysteine, leucine, isoleucine, lactate, succinate, formate, acetate, propionate, butyrate, fructose, cellobiose, xylose, glucose, mannose, mannitol, maltose, ribose, sucrose, lactose, galactose, arabinose, raffinose, glycerol, methanol, ethanol or inositol either in the presence or the absence of thiosulfate or sulfur.

End products from peptone fermentation and respiration were measured by HPLC (LC-20AT; Shimadzu Prominence) equipped with a reverse-phase C18 ultra aqueous column $(150 \mathrm{~mm} \times 4.6 \mathrm{~mm} \mathrm{ID})$ and a diode array detector (SPD$\mathrm{M} 20 \mathrm{~A})$ at $210 \mathrm{~nm}$. The end products detected from peptone fermentation were acetate, succinate, propionate and traces of ethanol. In the presence of thiosulfate, the only end products detected were acetate and succinate.

Using the whole genome amplification method (Ogg \& Patel, 2009), the $\mathrm{G}+\mathrm{C}$ content of the DNA of strain USBA $82^{\mathrm{T}}$ was calculated to be $52 \mathrm{~mol} \%\left(T_{\mathrm{m}}\right)$.

DNA purification, PCR amplification and sequencing of the 16S rRNA gene were performed as described by Andrews \& Patel (1996). Raw sequence data were imported into BioEdit, version 5.0.9 (Hall, 1999), the base calling was carefully examined and a contiguous consensus sequence of 1388 bp was generated. Using this consensus sequence, the closest relatives identified against the GenBank database (Altschul et al., 1997; Benson et al., 1999) using BLASTN and against the Ribosomal Database Project using the Sequence Aligner Program (Maidak et al., 2001) were downloaded. The sequences were aligned and positions of sequence and alignment ambiguity were omitted. A pairwise evolutionary distance matrix was generated using the method of Jukes \& Cantor (1969) and a dendrogram was constructed using the neighbour-joining method (Saitou \& Nei, 1987) as implemented in TREECON (Van de Peer \& De Wachter, 1994). Confidence in the tree topology was determined by using 1000 bootstrapped trees (Felsenstein, 1985). Phylogenetic analysis placed strain USBA $82^{\mathrm{T}}$ in the phylum Synergistetes, closest to Dethiosulfovibrio peptidovorans DSM $11002^{\mathrm{T}}$ (93\% gene sequence similarity) (Magot et al., 1997) (Fig. 1).

Strain USBA $82^{\mathrm{T}}$ and D. peptidovorans DSM $11002^{\mathrm{T}}$ shared the ability to ferment yeast extract, peptone, tryptone, 


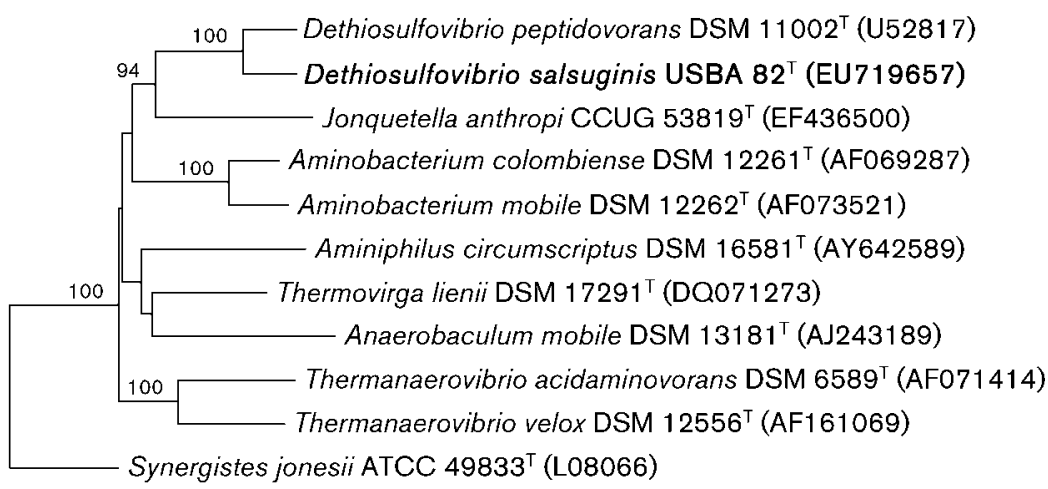

Fig. 1. Neighbour-joining dendrogram showing the phylogenetic position of strain USBA $82^{\top}$ and its closest relatives. GenBank accession numbers are given in parentheses. Bootstrap values $>90 \%$ are shown. Bar, 10 nucleotide changes per 100 nucleotides.

Casamino acids, serine and histidine and the inability to use carbohydrates, fatty acids and organic acids as sole carbon and energy sources. Both strains reduced the electron acceptors sulfur and thiosulfate to sulfide. Sulfur or thiosulfate was obligately required by $D$. peptidovorans for growth on the amino acids arginine, glutamate and valine, but not by strain USBA $82^{\mathrm{T}}$ which grew on these amino acids fermentatively (Table 1). Strain USBA $82^{\mathrm{T}}$ could also be differentiated from $D$. peptidovorans by its ability to ferment threonine and citrate and its inability to use alanine, isoleucine and leucine in the presence or absence of sulfur or thiosulfate (Table 1). On the basis of its phenotypic characteristics, the phylogeny based on $16 \mathrm{~S}$ rRNA gene sequence analysis and its $\mathrm{G}+\mathrm{C}$ content, strain USBA $82^{\mathrm{T}}$ may be categorized as a novel member of the genus Dethiosulfovibrio, for which the name Dethiosulfovibrio salsuginis sp. nov. is proposed.

\section{Description of Dethiosulfovibrio salsuginis sp. nov.}

Dethiosulfovibrio salsuginis (sal.su'gi.nis. L. gen. n. salsuginis of salt water).

Cells stain Gram-negative and are slightly curved or vibrioid-like rods with rounded or pointed ends, 5$7 \times 1.5 \mu \mathrm{m}$. Cells are highly motile by means of lateral flagella. Endospores are not formed. Obligately anaerobic. Growth occurs in media containing $0.1-6.0 \%(\mathrm{w} / \mathrm{v}) \mathrm{NaCl}$; $2 \%(\mathrm{w} / \mathrm{v})$ is optimal for growth. $\mathrm{NaCl}$ is tolerated up to $7 \%$, but no growth occurs at $8 \%$ or below $0.01 \%$. The $\mathrm{pH}$ range

Table 1. Physiological characteristics of strain USBA $82^{\top}$ and the type species of the genus Dethiosulfovibrio

Strains: 1 , USBA $82^{\mathrm{T}} ; 2$, D. peptidovorans DSM $11002^{\mathrm{T}}$ (data from Magot et al., 1997). + , Positive; - , negative; $+{ }^{1}$, used only in the presence of thiosulfate or sulfur; ND, not determined. Neither of the strains use lactate, formate, acetate, propionate, butyrate, succinate, ethanol, methanol, glycerol or mannitol. Both taxa reduce sulfur and thiosulfate to sulfide, but do not reduce sulfate to sulfide.

\begin{tabular}{|c|c|c|}
\hline Characteristic & 1 & 2 \\
\hline Sampling site & Saline spring & Corroding offshore oil well \\
\hline Cell morphology & Curved rods or spirals & Vibrio \\
\hline Cell size $(\mu \mathrm{m})$ & $1.5 \times 5-7$ & $1 \times 3-5$ \\
\hline DNA G $+\mathrm{C}$ content $(\mathrm{mol} \%)$ & 52 & 56 \\
\hline Temp. range (optimum) $\left({ }^{\circ} \mathrm{C}\right)$ & $20-40(30)$ & $20-45(42)$ \\
\hline $\mathrm{NaCl}$ range $(\% \mathrm{w} / \mathrm{v})$ (optimum) & $0.1-7(2)$ & (3) \\
\hline $\mathrm{pH}$ range (optimum) & $5.5-8.5(7.3)$ & $5.5-8.8(7.0)$ \\
\hline \multicolumn{3}{|l|}{ Utilization of: } \\
\hline Alanine & - & $+{ }^{1}$ \\
\hline Arginine & + & $+{ }^{1}$ \\
\hline Citrate & + & - \\
\hline Cysteine & - & ND \\
\hline Glutamate & + & $+{ }^{1}$ \\
\hline Isoleucine & - & $+{ }^{1}$ \\
\hline Leucine & - & $+{ }^{1}$ \\
\hline Lysine & - & - \\
\hline Pyruvate & + & ND \\
\hline Threonine & + & - \\
\hline Valine & - & $+{ }^{1}$ \\
\hline
\end{tabular}


for growth is 5.5-8.5 with an optimum at $\mathrm{pH}$ 7.3. The temperature range for growth is $20-40{ }^{\circ} \mathrm{C}$ with an optimum at $30{ }^{\circ} \mathrm{C}$. The type strain is able to reduce elemental sulfur (weakly) and thiosulfate when growing on peptone, but is not able to reduce sulfate, sulfite, nitrate or nitrite. Ferments pyruvate, citrate, Casamino acids, peptone, tryptone, serine, histidine, threonine, arginine and glutamate. Growth does not occur on lysine, glycine, proline, valine, alanine, cysteine, leucine, isoleucine, lactate, succinate, formate, acetate, propionate, butyrate, fructose, cellobiose, xylose, glucose, mannose, mannitol, maltose, ribose, sucrose, lactose, galactose, arabinose, raffinose, glycerol, methanol, ethanol or inositol either the presence or the absence of thiosulfate or sulfur. The main end products of fermentation are acetate and succinate.

The type strain, USBA $82^{\mathrm{T}}\left(=\right.$ DSM $\left.21565^{\mathrm{T}}=\mathrm{KCTC} 5659^{\mathrm{T}}\right)$, was isolated from the Salpa saline spring. The DNA G + C content of the type strain is $52 \mathrm{~mol} \%$.

\section{Acknowledgements}

The authors are grateful to the Instituto Colombiano para el Desarrollo de la Ciencia y la Tecnología (Colciencias) and International Foundations Science (IFS). Special gratitude is expressed to Carolina Rubiano, Luisa Fernanda Bernal and Javier Gómez for chromatographic analysis.

\section{References}

Alfaro, C. (2002). Geoquímica del Sistema Geotérmico de Paipa. Documento interno ministerio de Minas y Energía - INGEOMINAS, p. 40. Bogotá, Colombia: Proyecto Exploración y Evaluación de los Recursos Geotérmicos (in Spanish).

Altschul, S. F., Madden, T. L., Schäffer, A. A., Zhang, J., Zhang, Z., Miller, W. \& Lipman, D. J. (1997). Gapped BLAST and PSI-BLAST: a new generation of protein database search programs. Nucleic Acids Res 25, 3389-3402.

Andrews, K. T. \& Patel, B. K. C. (1996). Fervidobacterium gondwanense sp. nov., a new thermophilic anaerobic bacterium isolated from nonvolcanically heated geothermal waters of the Great Artesian Basin of Australia. Int J Syst Bacteriol 46, 265-269.

Baena, S., Fardeau, M.-L., Labat, M., Ollivier, B., Garcia, J.-L. \& Patel, B. K. C. (1998). Aminobacterium colombiense gen. nov. sp. nov., an amino acid-degrading anaerobe isolated from anaerobic sludge. Anaerobe 4, 241-250.

Baena, S., Fardeau, M.-L., Woo, T. H. S., Ollivier, B., Labat, M. \& Patel, B. K. C. (1999a). Phylogenetic relationships of three amino-acid utilizing anaerobes, Selenomonas acidaminovorans, 'Selenomonas acidaminophila' and Eubacterium acidaminophilum, as inferred from partial 16S rDNA nucleotide sequences and proposal of Thermanaerovibrio acidaminovorans gen. nov., comb. nov. and Anaeromusa acidaminophila gen. nov., comb. nov. Int $J$ Syst Bacteriol 49, 969-974.

Baena, S., Fardeau, M.-L., Ollivier, B., Labat, M., Thomas, P., Garcia, J.-L. \& Patel, B. K. C. (1999b). Aminomonas paucivorans gen. nov., sp. nov., a mesophilic, anaerobic, amino-acid-utilizing bacterium. Int $J$ Syst Bacteriol 49, 975-982.

Benson, D. A., Boguski, M. S., Lipman, D. J., Ostell, J., Ouellette, B. F., Rapp, B. A. \& Wheeler, D. L. (1999). GenBank. Nucleic Acids Res 27, 12-17.
Cord-Ruwisch, R. (1985). A quick method for determination of dissolved and precipitated sulfides in cultures of sulfate-reducing bacteria. J Microbiol Methods 4, 33-36.

Dahle, H. \& Birkeland, N. K. (2006). Thermovirga lienii gen. nov., sp. nov., a novel moderately thermophilic, anaerobic, amino-aciddegrading bacterium isolated from a North Sea oil well. Int J Syst Evol Microbiol 56, 1539-1545.

Díaz, C., Baena, S., Fardeau, M. L. \& Patel, B. K. C. (2007). Aminiphilus circumscriptus gen. nov., sp. nov., an anaerobic aminoacid-degrading bacterium from an upflow anaerobic sludge reactor. Int J Syst Evol Microbiol 57, 1914-1918.

Felsenstein, J. (1985). Confidence limits on phylogenies: an approach using the bootstrap. Evolution 39, 783-791.

Ganesan, A., Chaussonnerie, S., Tarrade, A., Dauga, C., Bouchez, T., Pelletier, E., Le Paslier, D. \& Sghir, A. (2008). Cloacibacillus evryensis gen. nov., sp. nov., a novel asaccharolytic, mesophilic, amino-aciddegrading bacterium within the phylum 'Synergistetes', isolated from an anaerobic sludge digester. Int J Syst Evol Microbiol 58, 2003-2012.

Hall, T. A. (1999). BioEdit: a user-friendly biological sequence alignment editor and analysis program for Windows 95/98/NT. Nucleic Acids Symp Ser 41, 95-98.

Imhoff-Stuckle, D. \& Pfenning, N. (1983). Isolation and characterization of a nicotinic-acid degrading sulfate-reducing bacterium, Desulfococcus niacini sp. nov. Arch Microbiol 136, 194-198.

Jukes, T. H. \& Cantor, C. R. (1969). Evolution of protein molecules. In Mammalian Protein Metabolism, vol. 3, pp. 21-132. Edited by H. N. Munro. New York: Academic Press.

Jumas-Bilak, E., Carlier, J.-P., Jean-Pierre, H., Citron, D., Bernard, K., Damay, A., Gay, B., Teyssier, C., Campos, J. \& Marchandin, H. (2007). Jonquetella anthropi gen. nov., sp. nov., the first member of the candidate phylum 'Synergistetes' isolated from man. Int J Syst Evol Microbiol 57, 2743-2748.

Jumas-Bilak, E., Roudière, L. \& Marchandin, H. (2009). Description of Synergistetes phyl. nov. and emended description of the phylum Deferribacteres and of the family Syntrophomonadaceae, phylum Firmicutes. Int J Syst Evol Microbiol 59, 1028-1035.

Magot, M., Ravot, G., Campaignolle, X., Ollivier, B., Patel, B. K., Fardeau, M. L., Thomas, P., Crolet, J. L. \& Garcia, J. L. (1997). Dethiosulfovibrio peptidovorans gen. nov., sp. nov., a new anaerobic, slightly halophilic, thiosulfate-reducing bacterium from corroding offshore oil wells. Int J Syst Bacteriol 47, 818-824.

Maidak, B. L., Cole, J. R., Lilburn, T. G., Parker, C. T., Jr, Saxman, P. R., Farris, R. J., Garrity, G. M., Olsen, G. J., Schmidt, T. M. \& Tiedje, J. M. (2001). The RDP-II (Ribosomal Database Project). Nucleic Acids Res 29, 173-174.

Ogg, C. D. \& Patel, B. K. C. (2009). Caloramator australicus sp. nov., a thermophilic anaerobic bacterium from the Great Artesian Basin of Australia. Int J Syst Evol Microbiol 59, 95-101.

Patel, B. K. C., Morgan, H. W. \& Daniel, R. M. (1985). Fervidobacterium nodosum gen. nov. and spec. nov., a new chemoorganotrophic, caldoactive, anaerobic bacterium. Arch Microbiol 141, 63-69.

Rees, G. N., Patel, B. K. C., Grassia, G. S. \& Sheehy, A. J. (1997). Anaerobaculum thermoterrenum gen. nov., sp. nov., a novel, thermophilic bacterium which ferments citrate. Int J Syst Bacteriol 47, 150-154.

Saitou, N. \& Nei, M. (1987). The neighbor-joining method: a new method for reconstructing phylogenetic trees. Mol Biol Evol 4, 406-425.

Van de Peer, Y. \& De Wachter, R. (1994). TREECON for Windows: a software package for the construction and drawing of evolutionary trees for the Microsoft Windows environment. Comput Appl Biosci 10, 569-570.

Vartoukian, S. R., Palmer, R. M. \& Wade, W. G. (2007). The division "Synergistes". Anaerobe 13, 99-106. 